\title{
Implementasi Pendidikan Karakter Religius Melalui Budaya Sekolah di SMA Mujahidin Pontianak
}

\author{
Merja Erlanda ${ }^{1}$, Sulistyarini ${ }^{2}$, Syamsuri ${ }^{3}$ \\ ${ }^{1}$ Prodi PPKn FKIP, Universitas Tanjungpura \\ Email : merjaerlanda@gmail.com \\ ${ }^{2}$ Prodi PPKn FKIP, Universitas Tanjungpura \\ Email : sulistyarini@fkip.untan.ac.id \\ ${ }^{3}$ Prodi Pend. Ekonomi FKIP, Universitas Tanjungpura \\ Email : syamsuri@untan.ac.id
}

\begin{abstract}
This study aims to determine the implementation of religious character education through school culture at SMA Mujahidin Pontianak. This research is a descriptive study using a qualitative approach. The subjects in this study were school principals, PPKn teachers, Islamic religious education teachers, and students. The results of this study indicate that the implementation of religious character education through school culture at SMA Mujahidin Pontianak through routine activities, exemplary activities, spontaneous activities and conditioning. Routine activities are praying in congregation, reading short suras of the Qur'an and praying before and after learning, infaq every Friday, and class pickets Exemplary activities are from how to dress neatly and be polite and friendly as well as discipline from school principals, teachers, administrative staff and other education personnel. Spontaneous activities are in the form of giving donations if there are residents who are grieving. Conditioning is in the form of providing facilities such as prayer rooms, separate ablution places for boys and girls, storage areas for the Qur'an, slogans/posters with character values, provision of trash cans and a clean and tidy school environment.
\end{abstract}

Keywords : Implementation; Religious; Character Education; School Culture.

Abstrak. Penelitian ini bertujuan untuk mengetahui implementasi pendidikan karakter religius melalui budaya sekolah di SMA Mujahidin Pontianak. Penelitian ini merupakan penelitian deskriptif menggunakan pendekatan kualitatif. Subjek dalam penelitian ini adalah kepala sekolah, guru PPKn, guru pendidikan agama islam, dan peserta didik. Pemilihan subjek ini dipilih atas pertimbangan tertentu. Teknik pengumpulan data mengunakan observasi, wawancara, dan dokumentasi. Teknik analisis data menggunakan analisis reduksi data, display data, dan penarikan kesimpulan. Hasil penelitian ini menunjukan bahwa implementasi pendidikan karakter religius melalui budaya sekolah di SMA Mujahidin Pontianak melalui kegiatan rutin, kegiatan keteladan, kegiatan spontan dan pengondisian. Kegiatan rutin yaitu sholat berjama'ah, membaca surah-surah pendek al-qur'an serta berdo'a sebelum dan sesudah pembelajaran, infaq setiap hari jum'at, dan piket kelas. Kegiatan keteladanan yaitu melalui dari cara berpakaian yang rapi dan bersikap/berprilaku sopan dan ramah serta disiplin mulai dari kepala sekolah, guru, staff administrasi dan tenaga pendidikan lainnya. Kegiatan spontan yaitu berupa memberikan sumbangan apabila ada warga yang sedang berduka. Pengondisian yaitu berupa penyediaan fasilitas seperti mushola, tempat wudhu yang terpisah antara putra dan putri, tempat penyimpanan al-qur'an, sloga/poster yang nilai karakter, penyediaan tempat sampah seta lingkungan sekolah nyaman, bersih dan rapi.

Kata Kunci : Implementasi; Pendidikan Karakter; Religius, Budaya Sekolah. 


\section{PENDAHULUAN}

Pendidikan merupakan usaha sadar serta terencana dalam menciptakan ruang belajar dan proses pembelajaran agar peserta didik secara aktif mengembangkan kemampuan diri serta memiliki kekuatan spiritual, pengendalian diri, kepribadian dan pola pikir, akhlak mulia, serta keterampilan. "Pendidikan dan kegiatan belajar adalah dasar keberadaan manusia, sehingga manusia tidak dapat dipisahkan dari kegiatan belajar mengajar" (Sulistyarini et al., 2020). Pendidikan tidak boleh melupakan muatan dari pendidikan karakter karena pendidikan karakter bertujuan selain dapat membangun kecerdasan ilmiah, tetapi juga dapat membentuk moral dan prilaku peserta didik.

Pendidikan Karakter merupakan keseharusan didalam dunia pendidikan karena pendidikan karakter tidak hanya menjadikan peserta didik cerdas dalam berpikir tetapi pendidikan karakter juga dapat membangun budi pekerti dan sopan santun dalam kehidupan sehari-hari (Rohendi, 2016). Mempelajari karakter tidak terlepas juga mempelajari nilai atau sikap dan norma, serta moral. Salah satu unsur dalam karakter seseorang individu adalah sikap dan perilakunya (Bogomaz et al., 2015). Sama halnya juga pendidikan karakter religius yang memang dari awal menunjukan watak asli bangsa indonesia yang religius. Pendidikan karakter religius juga menjadi salah satu upaya dalam rangka untuk mengatasi degradasi moral yang terjadi pada generasi penerus bangsa ini. Hal tersebut terdapat didalam rumusan tujuan pendidikan nasional Undang-Undang No 20 Tahun 2003 bab II Pasal 3 sebagaimana yang dimaksud: Pendidikan nasionan berfungsi sebagai wujud pembentukan watak dan peradaban bangsa dalam mencerdaskan kehidupan bangsa sehingga menjadi manusia yang beriman dan bertakwa kepada Tuhan Yang Maha Esa.

Melihat dari rumusan tersebut jelas bahwa gol utama dari pendidikan nasional adalah terwujudnya keimanan dan ketakwaan. Hal ini sejalan dengan Pepres No 87 Tahun 2017 tentang penguatan pendidikan karakter yang tertera pada pasal 3 pendidikan karakter dilaksanakan dengan menerapkan nilai-nilai pancasila yang meliputi : religius, nasionalis, kemandirian, intergritas dan gotong royong.

Nilai religius menjadi pondasi utama dalam kokohnya pembangunan pendidikan karakter. Pendidikan karakter religius dapat memperbaiki diri dari segi tindakan serta perilaku seseorang yang akan mengarahkannya pada tata karma dan nilai kesopanan sehingga pendidikan karakter religius bermuara pada konservasi moral seseorang (Megawati, Sulistyarini, and Ulfah, 2017) Menurut (Kholis, 2017) "sekolah merupakan salah satu institusi yang memiliki tanggung jawab dalam melahirkan generasi bangsa yang berkarakter" Dalam mewujudkannya hal tersebut sangat diperlukan kerjasama dengan berbagai pihak lainnya seperti : keluarga dan masyarakat. Pendidikan memiliki peran penting dalam pengembangan karakter seseorang. Sejalan hasil penelitian (Syamsuri, 2019) bahwa sikap dan perilaku berhubungan erat dengan pembelajaran dimana sikap atau karakter mempengaruhi pembelajaran seseorang. Lanjut Lembaga pendidikan tidak hanya sebagai tempat mengtransfer ilmu pengetahuan saja, tetapi juga sebagai wadah pembentukan sikap, perilaku, karakter, dan kepemimpinan (Rokhman et al., 2014). Karakter tidak datang dengan sendirinya, tetapi harus dibangun dan ditata agar menjadi martabat bangsa yang berkarakter. Karakter tersebut dapat diwujudkan melalui langkah-langkah tertentu (Sulistyarini et al., 2020). Salah satunya wujud pengembangan karakter adalah melalui budaya sekolah (Pradana, 2016).

Sekolah juga harus menyadari keberadaan peran penting budaya sekolah yang dimana akan memberi pengaruh dalam pembentukan karakter tidak hanya bagi peserta didik tetapi juga bagi seluruh warga sekolah. Budaya sekolah dalam membentuk karakter harus melibatkan seluruh warga sekolah. Nilai-nilai yang dibangun harus berlandaskan sikap, tradisi, kegiatan keseharian dan simbolsimbol yang harus dipraktekan oleh seluruh warga sekolah. Beberapa upaya yang bisa dilakukan dalam mewujudkan kegiatan tersebut adalah memberikan contoh keteladanan, menciptakan lingkungan yang kondusif, dan ikut berperan aktif dalam penerapannya (Siswanto, 2013).

Pentingnya implementasi pendidikan karakter religius oleh sekolah melalui budaya sekolah yang berkarakter Dalam prakteknya pendidikan nasional pada saat ini terdapat perbedaan yang sangat nyata antara cita-cita pendidikan nasional dan kenyataan yang terjadi kalangan dimasyarakat. Bisa kita lihat diberbagai media informasi pemberitaan kekerasan yang dilakukan oleh seorang guru, 
kekerasan yang dilakukan peserta didik terhadap seorang guru, korupsi, penggunaan narkoba, tawuran antar pelajar, pergaulan bebas, dan banyak lagi tindakan asusila lainya yang jelas dapat merusak indikator karakter generasi bangsa ini. Seperti kasus yang terjadi di Ciamis, Jawa Barat. Seorang guru olahraga tega memukul dan mencekik muridnya yang duduk dibangku kelas IX hanya karna persoalan tak mencukur rambut di Madrasah Tsanawiyah, Ciamis, Jawa Barat yang terjadi pada Hari Senin, 17 Febuari 2020 di kantin sekolah. Sehingga korban mengalami trauma berat dan korban juga takut untuk masuk ke sekolah karna takut dengan guru olahraganya tersebut.

Kasus serupa juga terjadi di kecamatan Fatuleu, Kabupaten Kupang, NTT pada hari senin 2 Maret 2020. Tiga siswa tega injak kepala guru, pukul dan lempar kursi hanya karena menegur siswa tersebut dikarenakan belum menanda tangani daftar hadir, karena ketiga siswa tersebut merasa tersinggung dan malu dihadapan siswa lain. Mereka tega melakukan perbuatan keji itu kepada gurunya. Akibat perbuatannya itu, guru tersebut mengalami luka, bengkak, dan cidera di beberapa bagian tubuhnya. Dari kasus tersebut membuktikan bahwa pendidikan karakter tidaknya hanya dilakukan melaui pembelajaran tetapi juga perlu dilakukan melalui budaya sekolah sebagai upaya preventif agar karakter generasi muda Bangsa Indonesia dapat terus mengalami peningkatan sesuai norma dan nilai luhur pancasila.

Kualitas pendidikan karakter yang sebagaimana mestinya menjadi tujuan kita bersama bisa dilihat dari budaya sekolahnya. "Kunci keberhasilan terhadap budaya sekolah terletak pada individu itu sendiri sebagai warga sekolah sehingga setiap individu harus memahami arti perubahan dan pada akhirnya dapat memberikan partisipasi terhadap perubahan tersebut" (Widodo,2017). Budaya sekolah merupakan salah satu faktor penentu terhadap kualitas pendidikan yang bermutu dan berkualitas.

Hasil penelitian (Surya, 2012) dan (Siswanto, 2013) membuktikan budaya sekolah yang baik akan membentuk karakter yang baik pula bagi peserta didik dan seluruh warga sekolah tidak hanya melalui tata tertib sekolah ataupun melalui program-program khusus serta peran kepala sekolah dan guru, tetapi juga peran dari tenaga pendidikan lainya seperti melibatkan tenaga administrasi yang ada di sekolah sehingga dapat membangun penguatan budaya sekolah yang berkarakter. Sehingga penelitian ini mememiliki kesamaan yaitu tentang tentang pendidikan karakter melalui budaya sekolah, namun yang membedakan penelitian ini dengan penelitian tersebutlah ialah penelitian ini mencoba menggali peimplementasian pendidikan karakter secara khusus tantang pendidikan karakter religius melalui budaya sekolah yang menjadi kegiatan keseharian seperti kegiatan rutin, keteladanan, spontan, dan pengondisian.

Disaat mulai lemahnya karakter religius terhadap peserta didik di lingkungan pendidikan, ada salah satu sekolah yang berada di kota Pontianak yang membentuk budaya sekolah sebagai upaya penanaman karakter religius kepada peserta didik yaitu, SMA Mujahidin Pontianak yang terletak di komplek mujahidin Pontianak Jl. Jendral Ahmad Yani, Kelurahan Acaya, Kecamatan Pontianak Selatan. SMA Mujahidin Pontianak merupakan sekolah di bawah naungan yayasan mujahidin Pontianak yang berstatus swasta dengan menerapkan nuasa Islam sebagai landasan pelaksanakan karakter religius kepada peserta didik. SMA Mujahidin juga sudah terakreditasi A di kota Pontianak. ini membuktikan bahwa SMA Mujahidin Pontianak telah melaksanakan mutu sekolah yang sebagaimana menjadi tujuan pendidikan nasional. Hal ini merupakan prestasi bagi sekolah yang menerapkan pendidikan karakter religius berbasis Islam.

Berdasarkan hasil dari observasi awal mengenai implementasi pendidikan karakter religius di SMA Mujahidin Pontianak ditemukan beberapa kegiatan seperti sholat dzuhur berjmaah di masjid raya mujahidin, keteladanan yang ditunjukan oleh warga sekolah seperti datang tepat waktu, mengucapkan salam ketika masuk ruangan, dan guru selalu menegur peserta didik ketika berpakaian tidak rapi, kegiatan spontan seperti ada salah satu guru yang sedang sakit guru-guru pergi untuk menjenguk, serta pengondisian tata kelola ruangan yang rapi dan sistematis dengan tujuan agar suasana belajar menjadi kondusif.

Menurut peneliti pelaksanaan pendidikan karakter religius di SMA Mujahidin Pontianak telah dilaksanakan melalui aturan yang baku yang dimana menjadi kesepakatan bersama oleh seluruh 
warga sekolah yaitu mewajibkan warga sekolah untuk melaksanakan sholat berjamaah di masjid raya mujahidin pontianak semua upaya dari program pendidikan karakter tersebut dilakukan untuk membentuk budaya sekolah yang berkarakter terutama penanaman karakter relgius. Tujuan penelitian ini untuk mengetahui bagaimana Implementasi Pendidikan karakter Religius di SMA Mujahidin Pontianak Melalui Kegiatan Rutin, Kegiatan Keteladanan, Kegiatan Spontan Dan Pengondisian.

\section{METODE PENELITIAN}

Bentuk penelitian dalam penelitian ini adalah penelitian kualitatif dengan menggunakan metode deskriptif. Dalam penelitian ini yang menjadi objek pengamatan peneliti adalah kegiatan rutin, kegiatan keteladanan, kegiatan spontan, dan pengondisian yang sasaran utama implementasi pendidikan karakter religius adalah peserta didik yang di eksplor secara bersama untuk mendorong pengimplementasian pendidikan karakter religius di SMA Mujahidin Pontianak. Lokasi dalam penelitian ini di SMA Mujahidin Pontianak Jalan Jendral Ahmad Yani, Kelurahan Acaya, Kecamatan Pontianak Selatan, Kota Pontianak. Menurut (Sugiyono, 2018) "instrumen penelitian adalah suatu alat yang digunakan untuk mengukur fenomena alam maupun sosial yang sedang diamati oleh seorang peneliti". Dalam penelitian ini, yang menjadi instrumen peneliti ialah peneliti sendiri, karena peneliti secara langsung menjadi instrumen dilapangan. Sumber data dalam penelitian ini yaitu sumber data primer dan sumber data skunder. Sumber data primer dalam penelitian ini adalah Kepala Sekolah, Guru PPKn, Guru Agama Islam, dan Siwa di SMA Mujahidin Pontianak. Sedangkan skunder adalah data yang berupa dokumen yang berkaitan dengan penelitian sehingga dapat membantu penemuan hasil penelitian yang di peroleh dari Kepala Sekolah, Guru PPKn, Guru Agama Islam, dan Siwa di SMA Mujahidin Pontianak.

Teknik pengumpulan data yang dalam penelitian ini yaitu menggunganakan pedoman observasi, pedoman wawancara, dan dokumentasi. Sedangkan alat pengumpulan data yang digunakan pada penelitian ini peneliti dengan observasi dan pedoman wawancara. Teknik analisis data yang digunakan dalam penelitian ini yaitu reduction (reduksi data), display (penyajian data), dan conlusion drawing/verification. Sedangkan untuk rencana ujian keabsahan data peneliti menggunakan triangulasi sumber dan triangulasi teknik.

\section{HASIL DAN PEMBAHASAN}

Berdasarkan data hasil temuan dan analisis data dalam penelitian ini, maka peneliti akan membahas mengenai bagaimana implementasi pendidikan karakter religius melalui budaya sekolah di SMA Mujahidin Pontianak selanjutnya dijabarkan sebagai berikut :

\section{Implementasi Pendidikan Karakter Religius Melalui Kegiatan Rutin di SMA Mujahidin Pontianak}

a. Program/Kegiatan Sholat Dzuhur Berjam'ah

Salah satu program/kegiatan yang bertujuan pengilmplementasian dan menguatkan karakter religius khususnya peserta didik yaitu mewajibkan seluruh warga sekolah untuk sholat berjamaah di masjid raya mujahidin pontianak. Kegiatan tersebut dapat meningkatkan nilai karakter religius. Sholat berjama'ah akan dapat menjadi bekal bagi peserta didik di lingkungan sekolah untuk berprilaku sesuai moral dan etika (Kurniawan, 2016). Kegiatan tersebut juga merupakan implementasi pendidikan karakter religius melalui kegiatan rutin di SMA Mujahidin Pontianak.

b. Program/Kegiatan Membaca Surah-Surah Pendek Al-Qur'an

Kegiatan membaca surah-surah pendek sebelum pembelajaran dimulai rutin dilakukan di SMA Mujahidin Pontianak tidak hanya berpatokan pada pembelajaran agama saja tetapi pada semua mata pelajaran hal tersebut sudah menjadi ketentuan dari yayasan mujahidin pontianak dan disekapakati oleh kepala sekolah SMA Mujahidin Pontianak. Dalam kegiatan membaca 
surah-surah pendek ini dipandu oleh ketua kelas dan guru yang mengajar pada saat itu mengawasinya. Jumlah surah pendek yang dibaca ada 5 surah yang memang ditentukan oleh setiap guru yang mengajar kegiatan ini selain dapat membawa kebaikan bagi peserta didik juga akan mudah menghafal surah-surah pendek al-qur'an.

\section{c. Program/Kegiatan Berdo'a Sebelum dan Sesudah Pembelajaran}

Kegiatan tersebut dapat meningkatkan nilai karakter religius yang melibat tuhan dalam segala kegiatan. Berdo'a merupakan nilai keimanan yang dimiliki oleh seseorang sehingga nilai keimanan tidak dapat di pisahkan dari diri seseorang sejak ia lahir dan pertama kali di dapatkan di lingkungan keluarga sehingga ketika anak-anak masuk ke lingkungan sekolah nilai keimanan dengan pandangan agama yang mereka miliki akan muncul juga di lingkungan sekolah sehingga ini akan menjadikannya sangat religius (Unstad dan Fjortoft, 2021). Kegiatan tersebut juga merupakan indikator keberhasila implementasi pendidikan karakter religius sebagaimana yang dimaksud Kemendiknas tahun 2010 yaitu berdo'a sebelum dan sesudah pembelajaran.

Jadi dapat peneliti simpulkan dari penjelasan hasil penelitian Implementasi Pendidikan Karakter Religius Melalui Budaya Sekolah yaitu : berdo'a sebelum dan sesudah pembelajaran kegiatan tersebut sudah sesuai dengan tujuan pendidikan nasional UU No. 20 Tahun 2003 yang dimana mengedepankan keimanan dan ketakwaan dan juga mengenai nilai karakter religius dari kegiatan tersebut ialah nilai karakter religius yang mencerminkan keberimanan kepada Tuhan Yang Maha Esa yang diwujudkan dalam prilaku melaksanakan ajaran agaman dan kepercayaan yang dianut.

\section{d. Program/Kegiatan Infaq Setiap Hari Jum'at}

Kegiatan infaq yang dilakukan secara rutin di SMA Mujahidin Pontianak setiap hari jum'at merupakan implementasi pendidikan karakter religius yang dimana mengajarkan anak untuk menyisihkan sedikit uang nya yang dimana ini akan mengajarkan anak untuk terbiasa bersedekah dan membantu sesama yang membutuh. Dana infaq yang terkumpul dari kegiatan tersebut biasanya di pergunakan untuk santunan ke panti-panti setiap tahunnya, bencana sosial, serta bagi warga sekolah yang tertimpa musibah. Hal ini sejalan dengan nilai pendidikan karakter religius yang di maksud Menurut Kemendikbud dalam buku Konsep dan Pedoman Penguatan Pendidikan Karakter Tahun 2017 nilai karakter relgius sebagai bentuk empati terhadap sesama dengan melindungi yang kecil dan tersisih. Dapat peneliti simpulkan bahwa kegiatan infaq setiap hari jum'at yang di SMA Mujahidin Pontianak merupakan implementasi pendidikan karakter religius yang dimana nilai karakter relgius yang terkandung adalah melindungi yang kecil dan tersisih.

\section{e. Program/Kegiatan Membersihkan Ruang Kelas}

Kegiatan membersihkan ruangan kelas merupakan implementasi pendidikan karakter religius yang mencintai lingkungan agar kondisi dan suasana belajar terasa nyaman dengan kondisi ruangan kelas yang bersih dan rapi sebagaimana yang dimaksud Kemendiknas tahun 2011 dalam buku Konsep dan Pedoman Penguatan Pendidikan Karakter Tahun 2017 "Nilai karakter religius meliputi tiga dimensi relasi sekaligus, yaitu hubungan individu dengan Tuhan, individu dengan sesama dan individu dengan alam semesta (lingkungan)". Adapun sub nilai dari karakter religius tersebut salah satunya adalah mencintai lingkungan. Kegiatan tersebut dilakukan secara rutin oleh peserta didik setiap harinya dengan jadwal yang sudah di tentukan oleh wali kelas masing-masing.

Berdasarkan hasil penelitian dapat disimpulkan bahwa implementasi pendidikan karakter religius yang dilakukan oleh SMA Mujahidin Pontianak melaui prgram/kegiatan rutin yaitu sholat dzuhur berjamaah, membaca surah-surah pendek al-qur'an, berdo'a sebelum dan sesudah pembelajaran, infaq setiap hari jum'at dan piket kelas. Pemaparan tersebut sejalan dengan pernyataan dari (Muhtadi, 2011) menyatakan implementasi pendidikan karakter melalui kegiatan rutin merupakan kegiatan yang dilakukan peserta didik secara terus-menerus dan konsisten setiap saat. Contoh berbaris masuk kelas, berdo'a 
sebelum dan sesudah kegiatan, mengucap salam bila bertemu orang lain, dan membersihkan ruang kelas. Pada kegiatan/program tersebut akan muncul nilai karakter religius serta nilai karakter yang lainnya juga akan muncul seperti gotong royong dan intergritas. Nilai Karakter religius tersebut sejalan pernyataan (Kurniawan, 2016) yang menyatakan bahwa : Kegiatan religius yang dapat di terapkan kepada peserta didik di sekolah dapat di jadikan sebagai pembiasaan diantaranya yaitu : berdoa'a, melakasanakan kegiatan di mushola, merayakan hari raya keagamaan sesuai dengan agamanya, mengadakan kegiatan keagamaan sesuai dengan agamanya.

\section{Implementasi Pendidikan Karakter Religius Melalui Kegiatan Keteladanan di SMA Mujahidin Pontianak}

Nilai karakter kedisiplinan dan kerapian guru dalam berpakaian sehingga menjadi keteladanan dan diikuti peserta didik sebagai nilai karakter yang baik. Tugas seorang guru tidak hanya mengajarkan tentang konsep moral berdasarkan agama tetapi juga memberikan contoh prilaku moral yang baik berdasarkan keyakinan agamanya jadi siswa tidak hanya belajar tetapi juga dapat meniru prilaku tersebut dan di terapkan di lingkungan sekitarnya (Gholami, Maleki, dan Rizi, 2011). Dengan adanya kegiatan tersebut maka akan muncul nilai karakter religius tak hanya nilai karakter religius yang muncul nilai karakter intergritas juga akan muncul.

Berdasarkan hasil penelitian dapat disimpulkan bahwa implementasi pendidikan karakter religius yang dilakukan oleh SMA Mujahidin Pontianak melaui prgram/kegiatan keteladan yaitu cara berpakaian dan sikap prilaku kepala sekolah, guru, staff administrasi, tenaga pendidikan dan seluruh warga sekolah yang patut dijadikan contoh bagi peseta didik yang peneliti temui seluruh warga sekolah selalu mengenakan pakai yang rapi dan sopan sesuai dengan jadwal penugasan pakaian tertentu pada hari tertentu guru selalu menegur ketika terdapat peserta didik yang berpakaian tidak rapi dalam mengenakan seragam Selain dari berpakain rapi seluruh warga sekolah juga selalu berupaya untuk berprilaku sopan, saling menyapa ketika bertemu sesama guru dan seluruh warga sekolah sehingga hal tersebut menjadi teladan bagi peserta didik saat bertemu teman, guru, tenaga pendidikan dan seluruh warga sekolah selalu untuk menyapa baik mengucapkan salam maupun bersalaman. Dengan adanya keteladanan maka akan muncul karakter religius tak hanya nilai karakter religius nilai karakter intergritas. Sejalan dengan pernyataan (Muhtadi, 2011) menyatakan implementasi pendidikan karakter dalam Kegiatan keteladanan merupakan kegiatan sehari-hari dimana guru, kepala sekolah, staf administrasi, bahkan juga pengawas harus dapat menjadi teladan atau model yang baik bagi murid-murid di sekolah. Sebagai contoh, jika guru hendak mengajarkan kesabaran kepada siswanya, maka terlebih dahulu guru harus mampu menjadi sosok yang sabar dihadapan muridmuridnya.

Nilai karakter religius tersebut juga sejalan dengan pernyataan (Lubab, 2017) yang menyatakan bahwa Nilai-nilai karakter religius yang ditanamakan kepada peserta didik antara lain yaitu keimanan, kejujuran, kedisiplinan, tanggung jawab, kasih sayang dan saling menghormati. Adapun keseluruhan Metode yang digunakan untuk penanaman nilai religius siswa yakni : keteladanan, pembiasaan, nasehat, pengawasan, dan ganjaran serta hukuman.

\section{Implementasi Pendidikan Karakter Religius Melalui Kegiatan Spontan di SMA Mujahidin Pontianak}

Terdapat kegiatan implementasi pendidikan karakter religius di SMA Mujahidin Pontianak yaitu memberikan sumbangan berupa materil dan non materil terhadap warga sekolah yang tertimpa musibah/berduka adalah salah satu contoh kegiatan spontan yang di lakukan oleh SMA Mujahidin Pontianak seperti kegiatan peduli sosial terhadap warga sekolah yang tertimpa musibah/berduka dengan memberikan sebagian rezeki kita untuk disumbangkan kepada warga 
sekolah yang sedang tertimpah musibah/berduka. Hal tersebut sejalan dengan pernyataan (Niculescu dan Norel, 2013) "agama akan mendapat pemahaman yang berbeda jika dilihat dari inti persoalan agama itu sendiri namun bagi tenaga pendidik di suatu pendidikan formal seorang tanaga pendidik harus dapat mengembangkan nilai inti dan nilai bersama yang menjadi pegangan agama untuk peseta didik tidak peduli apaun agama meraka". Nilai karakter religius yang terwujud dari kegiatan tersebut adalah melindungi yang kecil dan tersisih (Kemendiknas, 2010). Dapat di pahami bahwa kegiatan memberikan sumbangan terhadap warga sekolah yang tertimpa musibah merupakan kegiatan yang bernilai karakter religius siapapun apaun agama, suku, ras dan etnis yang sedang terimpa musibah sekolah tetap melakukan kegiatan sumbangan sebagai bentuk kepedulian sosial terhadap warga sekolah yang sedang tertimpa musibah. Pada kegiatan tersebut muncul nilai karakter religius dan tak hanya nilai karakter relgius nilai karakter gotong royong dan intergritas juga muncul dari kegiatan tersebut.

Berdasarkan hasil penelitian dapat disimpulkan bahwa implementasi pendidikan karakter religius yang dilakukan oleh SMA Mujahidin Pontianak melaui prgram/kegiatan spontan yaitu kegiatan peduli sosial misalnya mengintruksikan kepada peserta didik untuk memberikan sumbangan apabila ada peserta didik yang sedang berduka atau tetimpa musibah. Dengan adanya kegiatan yang dilakukan oleh warga sekolah akan menimbulkan nilai karakter religius pada peserta didik tak hanya nilai karakter religius yang akan muncul nilai karakter gotong royong dan intergritas juga akan muncul. Sejalan dengan pernyataan (Muhtadi, 2011) menyatakan implementasi pendidikan karakter dalam kegiatan spontan yaitu kegiatan yang dilaksanakan secara spontan pada saat itu juga. Misalnya menjenguk teman yang sakit atau sedang tertimpa musibah kegiatan spontan biasanya juga dilakukan pada saat guru mengetahui atau melihat sikap atau tingkah laku peserta didik yang kurang baik.

Nilai karakter religius tersebut sejalan dengan pernyataan (Kurniawan, 2016) yang menyatakan, Religius merupakan sikap batin seseorang ketika berhadapan dengan realitas kehidupan di luar dirinya misalnya, hidup, mati, kelahiran, bencana, banjir, tanah longsor, gempa bumi, dan sebagainya.

\section{Implementasi Pendidikan Karakter Religius Melalui Pengondisian di SMA Mujahidin Pontianak.}

Berdasarkan hasil penelitian dapat disimpulkan bahwa implementasi pendidikan karakter religius yang dilakukan oleh SMA Mujahidin Pontianak melaui prgram/kegiatan pengondisian yaitu penyediaan fasilitas seperti poster/slogan-slogan yang bernilai karakter serta dapat memotivasi warga sekolah yang banyak terpanjang di sekolah dan tata letak ruang yang berada disekolah rapi, bersih dan strategis contoh ruang guru, ruang kelas, mushola, tempat wudhu yang terpisah putra dan putri, penyediaan tempat sampah di setiap kelas dan lapangan yang bersih dan hijau dengan pepohonan yang sehingga lingkungan sekolah terasa nyaman, bersih dan rapi. Hal tersebut sejalan dengan pernyataan (Muhtadi, 2011) implementasi pendidikan karakter melalui kegiatan pengondisian yang dimana suasana lingkungan sekolah dikondisikan dengan penyediaan sarana fisik sehingga dapat menunjang tercapainya tujuan pendidikan karakter yaitu dengan penyediaan tempat sampah, slogan-slogan mengenai nilai-nilai moral yang mudah dibaca oleh peserta didik, dan aturan/tata tertib sekolah yang ditempelkan pada tempat yang strategis sehingga mudah dibaca oleh warga sekolah. Sejalan dengan (Kemendiknas, 2011) Kegiatan tersebut merupakan nilai karakter religius yang mencintai lingkungan, dan melindungi yang kecil dan tersisih.

Pada pernyataan Muhtadi dan Kemendiknas diatas tentang aspek pengondisian dan kaitan dengan hasil obsevasi dan wawancara yang peneliti lakukan bahwa aspek pengondisian yang peneliti temui di lapangan sudah sesuai dengan paparan dari pernyataan oleh Muhtadi tentang empat pengembang budaya sekolah yaitu kegiatan rutin, kegiatan keteladanan, kegiatan spontan dan pengondisian yang dimana pada aspek pengondisian yang telah peneliti 
observasi mengenai pengondisian yaitu penyediaan fasilitas seperti mushola, tempat wudhu yang terpisah antara putra dan putri, tempat penyimpanan al-qur'an, sloga/poster yang nilai karakter, penyedian tempat sampah seta lingkungan sekolah nyaman, bersih dan rapi. Sehingga ini akan berdampak pada pengembangan karakter peserta didik. Dengan adanya kegiatan tersebut dapat menimbulkan nilai karakter religius yaitu peduli lingkungan dan nilai karakter lain juga akan muncul seperti mandiri, intergritas dan gotong royong.

\section{KESIMPULAN}

Berdasarkan hasil penelitian dan pembahasan yang telah peneliti lakukan dapat di simpulkan hasil penelitian sebagai berikut :

1. Implementasi Pendidikan Karakter Religius Melalui Kegiatan Rutin di SMA Mujahidin Pontianak dilakukan melalui program/kegiatan yaitu, Sholat dzuhur berjamaah, membaca surah-surah pendek al-qur'an, berdo'a sebelum dan sesudah pembelajaran, kegiatan infaq setiap hari jum'at, dan kegiatan piket kelas. Pada program/kegiatan tersebut akan memunculkan karakter religius tak hanya karakter religius nilai karakter gotong royong dan intergritas juga akan muncul.

2. Implementasi Pendidikan Karakter Religius Melalui Kegiatan Keteladanan di SMA Mujahidin Pontianak dilakukan melalui dari cara berpakaian dan bersikap/berprilaku oleh kepala sekolah, guru, staff administrasi dan tenaga pendidikan lainnya yang patut dijadikan contoh bagi peserta didik seperti yang peneliti temukan bahwa kepala sekolah, guru, staff administrasi dan tenaga pendidikan selalu berpakaian rapi dan sopan sesuai dengan jadwal penggunaan pakaian tertentu di hari tertentu sehingga terlihat kompak dan rapi dalam berpakaian sehingga hal tersebut menjadi teladan dan contoh bagi peserta didik untuk selalu mengenakan seragam sekolah yang rapi. Nilai karakter religius akan muncul ketika kepala sekolah, guru, staff administrasi dan tenaga pendidikan memberikan contoh sikap keteladanan tersebut.

3. Implementasi Pendidikan Karakter Religius Melalui Kegiatan Spontan di SMA Mujahidin Pontianak dilakukan melalui kegiatan peduli sosial misalnya memberikan sumbangan apabila ada warga yang sedang berduka. Dengan adanya kegiatan tersebut akan muncu nilai karakter religius tak hanya nilai karakter religius nilai karakter gotong royong dan intergritas juga akan muncul dari kegiatan tersebut.

4. Implementasi Pendidikan Karakter Religius Melalui Kegiatan Pengondisian di SMA Mujahidin Pontianak pada kegiatan pengondisian yang dapat peneliti simpulkan dari hasil penelitian yang peneliti lakukan bahwa pengondisian dalam implementasi pendidikan karakter religius ialah berupa penyediaan fasilitas seperti mushola, tempat wudhu yang terpisah antara putra dan putri, tempat penyimpanan al-qur'an, sloga/poster yang nilai karakter, penyedian tempat sampah seta lingkungan sekolah nyaman, bersih dan rapi. Dengan adanya kegiatan tersebut dapat menimbulkan nilai karakter religius yaitu peduli lingkungan dan nilai karakter lain juga akan muncul seperti mandiri, integritas dan gotong royong.

\section{DAFTAR PUSTAKA}

Bogomaz, S. A., Litvina, S. A., Kozlova, N. V., \& Atamanova, I. V. (2015). Culture-specific Subjective Evaluation of Character Strengths. Procedia - Social and Behavioral Sciences, 200(October), 92100. https://doi.org/10.1016/j.sbspro.2015.08.024

Kholis, N. (2017). Implementasi Pendidikan Karakter Berbasis Nilai-Nilai Islam Melalui Budaya Sekolah. 05(02), 047-065.

Lubab, S. B. B. (2017). Implementasi Penanaman Nilai-Nilai Religius Siswa di MTS Nurul Huda Dempet Demak.

Megawati, Sulistyarini, \& Ulfah, M. (2017). Implementasi Pendidikan Karakter Religius oleh Guru Dalam Pembelajaran Sosiologi Di SMA YPK Pontianak. Journal of Chemical Information and Modeling, 53(9), 1689-1699. 
Pradana, Y. (2016). Pengembangan Karakter Siswa Melalui Budaya Lokal (Studi Deskriptif di SD Amaliah Ciawi Bogor). 1(1), 1-10.

Rohendi, E. (2016). Pendidikan Karakter di Sekolah. 31(12), 723-730. https://doi.org/10.13347/j.cnki.mkaq.2010.09.001

Rokhman, F., Hum, M., Syaifudin, A., \& Yuliati. (2014). Character Education for Golden Generation 2045 (National Character Building for Indonesian Golden Years). Procedia - Social and Behavioral Sciences, 141, 1161-1165. https://doi.org/10.1016/j.sbspro.2014.05.197

Siswanto. (2013). Pendidikan Karakter Berbasis Nilai-Nilai Religius. Pendidikan Karakter, 8 Nomor 1 , 92-107.

Sulistyarini, Rosyid, R., Dewantara, J. A., \& Purwaningsih, E. (2020). Pancasila Character Education in Teaching Materials to Develop College Students' Civic Disposition. 418(Acec 2019), 325-330. https://doi.org/10.2991/assehr.k.200320.063

Surya, P. (2012). Peran Penting Tenaga Administrasi Sekolah Dalam Penguatan Budaya Sekolah untuk Implementasi Pendidikan Karakter. School Culture. https://doi.org/10.4135/9781446219362

Syamsuri, S. (2019). Analisis Konsep Theory Of Planned Behavior Terhadap Pembelajaran Wirausaha Dan Pendidikan Ekonomi Keluarga Pelaku Umkm. Jurnal PROFIT Kajian Pendidikan Ekonomi Dan Ilmu Ekonomi, 6(2), 101-113. https://doi.org/10.36706/jp.v6i2.9795

Widodo, H. (2017). Manajemen Perubahan Budaya Sekolah. MANAGERIA: Jurnal Manajemen Pendidikan Islam, 2(2), 287-306. https://doi.org/10.14421/manageria.2017.22-05 